\title{
Waste Throughout North Carolina with Implications for Agri- cultural Production
}

\author{
Edward L Kick ${ }^{1 *}$, Laura McKinney ${ }^{2}$, Ryan Thomson ${ }^{3}$ \\ ${ }^{1}$ Department of Agriculture and Resource Economics, North Carolina State University, USA. \\ ${ }^{2}$ Department of Sociology, Tulane University, USA. \\ ${ }^{3}$ Department of Sociology, University of Florida, USA.
}

*Corresponding author: Edward L. Kick, Department of Agriculture and Resource Economics, North Carolina State University, Room 3324 Nelson Hall Campus Box 8109 Raleigh, NC, USA. Tel: +1 27695-8109; E-mail: edkick@ncsu.edu.

Citation: Kick EL, McKinney L and Thomson R (2016). Waste throughout North Carolina with Implications for Agricultural Production. J Agr Agri Aspect 2016: JAAA-106.

Received Date: 30 November, 2016; Accepted Date: 10 December, 2016; Published Date: 17 December, 2016

\begin{abstract}
The purpose of this study is to explore facets of waste management: consumer recycling, industrial waste and disaster-related agricultural waste. We select the state of North Carolina for our quantitative and spatial analyses of these dynamics of interest. The multi-part study uses structural equation modeling (SEM) to assess the drivers of consumer recycling tonnage in rural and urban communities, geospatial information systems (GIS)and/or more routine mapping to analyze the spatial clustering of waste in the form of landfills, coal ash dumps, and agricultural waste (chicken and swine manure). Findings suggest that a structural understanding of waste recovery and containment is an important endeavor and we present a causal model suggesting a series of viable recovery and overall policy recommendations. These recommendations bear on the production of edible food locally and for the world market. Additionally, the study concludes, an emphasis on consumer behavior in recycling household waste could enhance national and global food security, as would vigilance in tracking waste, including that which is heightened by disasters, that reaches and contaminates waterways.
\end{abstract}

Keywords: Waste Management; Pollution; Recycling; Food; Industrial Waste; Spatial Inequality; SEM; GIS; Landfills; Coal Ash; Agriculture; Swine; Risk; Sustainability

\section{Introduction}

Exponential growth in production, consumption, and pernicious waste dumping cannot continue on a planet endowed with a finite amount of natural resources (Meadows, Randers, and Meadows 1972, Catton 1982, Bunker 1996, Bunker and Ciccantell 2005, Rees and Wackernagel 2013). The production of all commodities, their consumption, and disposal are all components in a holistic chain of actions which are presently exhausting the planet beyond its capacities for restoration (Catton 1980). This is the driving point behind environmental terms such as the "waste crisis," which some scholars use to refer to this particular material relation (Tammemagi 1999). For instance, the Global Footprint Network (2013) projects that humanity's material drawdown is roughly equivalent to 1.45 earth's regenerative capacity. These findings suggest that if everyone were to consume at the average rate of individuals in the United States, the production rate-to-waste deficit would demand no less than five planet earths to sustain consumption, production, and related waste generation. The implications for the 133 billion pounds of food farmed annually for human consumption but discarded by retailers and consumers alike is a human tragedy in a time of want, even in certain regions of the wealthiest countries (Jonathan Bloom, American Wasteland).

These findings as well as the concerns behind them are not new to scholarly or public audiences. Catton (1982) described this phenomena as 'the tragic case of human success,' which had been generalized in what he refers to as 'an age of exuberance.' His concern with overshooting ecological limitations expresses a historical relation in which "the people of one generation have become indirect and unwitting antagonists of subsequent generations." Throughout the US, we have observed the ambitious expansion of reduce, reuse, recycling and containment campaigns aimed at increasing food accessibility and material recovery from landfills, while stemming waste generally, to at least partially address the concerns Catton and others have raised.

\section{Materials and methods}




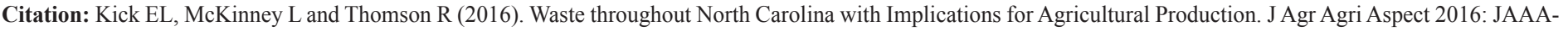
106.

For our purposes, local data were made available through the state of North Carolina Department of Environment and Natural Resources (DENR) and Southern Alliance for Clean Energy, as well as routinely available state demographic resources. The state of North Carolina offers an optimal setting for such an analysis given the expansion of material recovery across a range of demographic variations throughout three distinct ecological regions. Furthermore, North Carolina is home to both the world's largest utility company based in Charlotte as well as the enduring legacy of the environmental justice movement which emerged in Afton, North Carolina nearly two decades ago (Bullard 1990, 2005).

It is necessary to utilize multiple distinct methodological approaches in order to best assess both the causal dynamics of food and waste recovery as well as their spatial distribution. In part, the research design adapts to the absence of precise numerical data on the volume/weight of the toxins contained within landfills, coal ash dumps, and in waterways and soil at a distance from, for example, swine lagoons during the disasters that cause a comingling of these settings. These designs employed a geospatial information system, mapping, structural equation modeling (SEM), and overflight observation. SEM is a regression technique which simultaneously eliminates insignificant causes and highlights significant ones in an integrative regression model comprised of multiple causal linkages (of recycling). Multicollinearity, heteroscedasticity, measurement error and other problematics have been eliminated when detected.

GIS is used to assess the spatial distribution of toxins (in the form of coal ash and landfills) by analyzing geographically specific data. In order to compare these two particular types of pollution alongside one another, a range of spatial techniques (e.g. hot spot analysis, nearest neighbor analysis) is used to analyze their spatial relationships across various units. The investigation utilizes two mid-range geographical units, parceled townships and counties, in order to embed pollution in the local details of geography. GIS software offers a range of tools, methods and highly specialized techniques developed specifically to assess spatial relationships. Conceptually, spatial inequality operationalized as the inequality and corresponding markers of stratification across various spatial scales, geographies and places. In order to test for the existence of spatial inequality, Average Nearest Neighbor summary $(\mathrm{ANN}=\mathrm{DO} / \mathrm{DE})$, High-Low Clustering (Getis-Ord General G; see Appendix B), and Spatial Autocorrelation (see Morans 1950) all prove insightful in assessing geographical patterns. Secondary investigation makes use of a Hot-Spot Analysis (Getis-Ord G*; see Appendix B) to identify adjacent counties and municipalities that display a clustered pattern. All analyses utilize Euclidean distance (strict distances between pollution sites as well as an inverse distance conceptualization of spatial relationships), because it best represents the spatial model of pollution. Further inspection of publicly-available, disaster-related maps are used in the discussion of a third leg of analysis - a mapping of animal-related waste in the state. Unfortunately the proximity in time between a disaster and resulting short- run hog toxins limits our ability to generalize to the longer run.

\section{Literature Review}

\section{Recycling}

Recycling is one of the major mechanisms for retaining useable food and preventing the further creation of toxins of numerous varieties into productive material. Whether we consider landfills and the ameliorative recycling, or the many other forms of toxins (several of which we directly treat here), we emphasize the detrimental role of leachate exposure. Given the variability of leachate chemical contaminant signatures, framing the threat posed by contamination is not a simple endeavor. Leachate is the blanket term used to describe a general mixture of waste that contains some level of hazardous waste as decay sets in. Landfills (with compromised lining), coal ash (impoundments or otherwise), and swine lagoon pooling bring the risk of leachate exposure, which has been shown to be toxic, and often carcinogenic (Goodman, Hudson and Monteiro 1995). The life-threatening risks associated with this mixture is then further complicated by the seasonal and local variations of microbial plumes (see Brad et al. 2013). The classification system has grown increasingly sophisticated by adapting it to recognize and validate signature patterns with increased consistency (Tonjes 2013).

A number of studies have linked successful recycling, including the recycling of the products of agricultural production, to: the accessibility and convenience of recycling facilities (Guagnano, Stern and Dietz 1998; Harris Poll 2007), past recycling behavior (Ludemann 1999), self-identity (Terry, Hogg and White 1999), conformance to norms (Terry et al. 1999), subjective expected utility (Ludemann 1999), level of activist participation in national environmental organizations (Guerin, Crete and Mercier 2001), gender, education, and environmental beliefs (Saphores, Nixon, Ogunseitan and Shapiro 2006), public media, county and city context (Martinez and Scicchitano 1998), the goal of leading an "ecological lifestyle" (Nonami et al. 1997), and home ownership (Mainieri et al. 1997). Thus, attitudinal, attribute and community structural factors all may play integral roles in determining both food and general recycling behavior outcomes. What is needed, however, is an approach and analysis that more comprehensively examines these causes with macro-level factors (e.g., the "built capital" of a community, including the convenience of a broad range of creative recycling alternatives) in a more holistic, community-based model of recycling behavior outcomes. Instead of a piecemeal approach, we advocate theorizations and related empirical studies that integrate macro and micro domains believ- 
ing they will be most likely to lead to integrative programs that successfully increase community participation in recycling. Accumulated knowledge from the present study, which uses aggregated secondary data and on-site observational analysis hopefully will advance both science and public policy.

In addition, we note one rather comprehensive study of 30 Western states (Hornik, Cherian, Madansky and Narayana 1995) found that virtually no systematic causal agent predicted a state's increase or decrease in recycling levels. A state's wealth, education, exposure to recycling literature, publicity campaigns, speeches before adult and younger audiences, machinery for pick- up, and so on, seemed to make no difference whatsoever in recycling recovery rates. There was, however, one factor that seemed to foster successful recovery across the board - the convenience of technically appropriate food/waste recovery and recycling facilities. When the sorting of recyclables was not laboriously carried out by the homeowners, and when recyclables were instead retrieved by waste manage companies on a routinely announced basis, households offered up far greater levels of waste for recycling, and recycling tonnage soared.

\section{Analysis and Results}

\section{Recycling}

The data used in this portion of the study were made available to us through NC One Map Geographic Data Services, a state-level project of the NC Geographic Information Coordinating Council started in 2003. Data regarding active landfills were collected through the EPA Landfill Methane Outreach Program. Coal ash data were obtained through the Southern Alliance for Clean Energy and their partners. The data provided by the state of $\mathrm{NC}$ are point files and permit spatial assessments of the placement of landfills.

The state of NC has spaced out a potential landfill per county (100) and an additional 26, totaling to 126 landfills. Larger urban areas tend to have an additional landfill while small rural areas use the closest drop site opportunity. These sites tend to be selected based on the demand for disposal space as it relates to the availability of land. In order to decrease the chance of exposure, sites are often selected on the fringe areas surrounding urban areas but can become incorporated into the city limits as urban boundaries continue to expand. The unfortunate consequence is that leachate comes into direct contact with citizens that are a part of urban sprawl.

This is quite distinct from coal ash dumps which only recently received media attention following the spill in the Danville river basin. The state has at least 50 reported coal ash dumps containing at least 16 billion gallons of coal ash combustion waste concen- trated near fourteen coal plants located nearby a body of water. The data show that of the distinct sixty-four different dumps, only eleven are lined to prevent ground water contamination. It is important to note that lining is no guarantee that future hazards have been eliminated. Indeed, water contamination is linked with soil contamination and ultimately food toxins. This clearly is the case with agricultural production in the swine industry, where swine lagoons may overflow under disaster conditions, contaminating waterways.

In Figures 1 and 2 below we present findings for a model of 143 urban municipalities that report waste recycling tonnage, and then a separate model of the 77 rural (population less than 1500) municipalities. Compared to urban settings, the latter are most related to the dynamic of agricultural contamination. In 2013, the recycling recovery rate was roughly 14.4\% (NCDENR 2013 Annual Report). We differentiate the sample of rural areas because we found that an entirely different set of predictors were suited to model requirements (i.e. fit) in this setting than in larger municipalities. Our results for the urban municipalities are presented

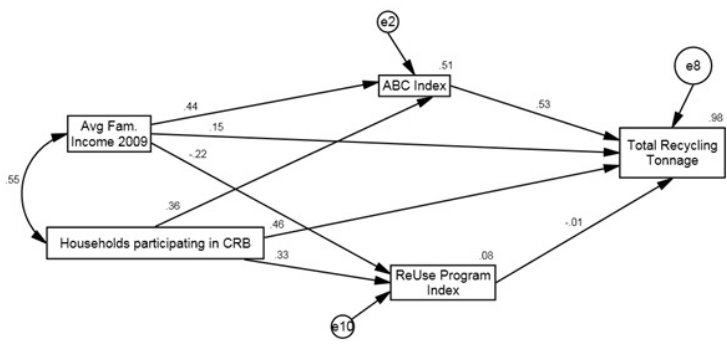

Figure 1: Recycled Tonnage of Waste: North Carolina Municipalities (n $=143$ )

All relationships statistically significant at the $\mathrm{p}<.05$ level or better (Except for relationship from reuse program index to outcome). Chisquare, not significant; RMSEA $=0.000 ; \mathrm{TLI}=1.014 ; \mathrm{IFI}=1.001 ; \mathrm{CFI}$ $=1.000$.

In 2005, a law was passed in NC that banned the disposal of recyclable containers by $\mathrm{ABC}$ permit holders into landfills or incinerators. This essentially required all $\mathrm{ABC}$ licensees (bars and restaurants that serve alcohol) to collect and recycle cans and bottles from their establishments. Many NC local governments decided to provide this service to the bars and restaurants either through a curbside or drop-off collection program. The results (ranging from +1.00 to -1.00 ) show that infrastructural determinants (e.g., household curbside recycling, collecting recycling from bars and restaurants) are direct and significant causal factors (coefficients $=.53$ and .46 , respectively) in generating higher rates of recycling tonnage. These conclusions are reached from the size of the coefficients on the lines from these variables to the total tonnage recycled variable at the far right hand end of the model. If these collection configu- 
Citation: Kick EL, McKinney L and Thomson R (2016). Waste throughout North Carolina with Implications for Agricultural Production. J Agr Agri Aspect 2016: JAAA106.

rations were adopted for food as well, positive food recovery and food security improvements are comparably high.

Coefficients of .46 (for curbside recycling) and .53 (for bar and restaurant recycling) are remarkably large for a study of this type. In contrast, the offering of workshops, forums and conferences that endeavored to heighten sensitivity to recycling and its benefits essentially have had no effect whatsoever. We note the relatively high coefficient between family income and providing recycling collection to bars and restaurants. Income makes a difference directly (.15) and indirectly (.44) by its impact on bar and restaurant recycling. This is completely in line with the results reported by the one comprehensive study of thirty Western states (Hornik, Cherian, Madansky and Narayana 1995). Convenience increases recycling participation, especially for families with the means (e.g. a reliable vehicle) to dispose of their glass waste to designated drop sites.

The rural sample, consider dropping second 'sample' most relevant for agricultural production, shows a range of causal factors. While population is included to render per capita the dependent variable and does not have a substantive interpretation, educational programs (.34) and college education itself (.37) enhance recycling tonnage. In rural settings, as compared with urban settings, programs that persuade citizens about the importance of recycling do in fact work! Farmers, by their nature, are "natural conservationists." Also, we find that rural municipalities with a relatively larger percent of military veterans have a high tonnage rate associated with their recycling program. Further inquiries into possible explanations revealed that military bases regularize recycling behaviors and make recycling very convenient, if not mandated. In contrast, a large percent of Hispanic citizens has a negative effect on recycling. Hispanic workers nonetheless are treated as essential for profit accumulation among rural farmers. The media works in boosting recycling in rural areas, thus it is possible that recycling messages offered across cultural venues will heighten food security and recycling effectiveness. To the point, we suggest that the recycling media adopt languages and translate as appropriate to the local culture when striving to convince that

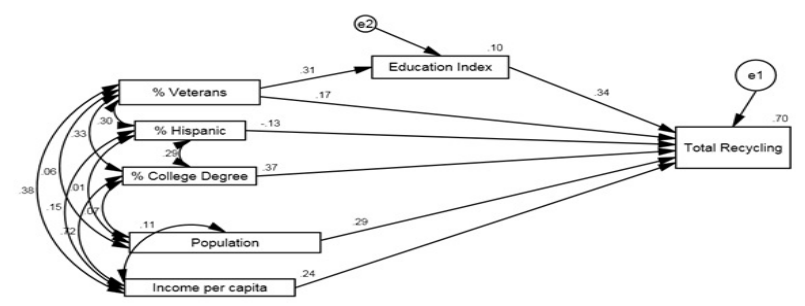

Figure 2: Recycled Tonnage of Waste: Rural North Carolina $(\mathrm{n}=77)$ (Population $<1500$ ) All relationships statistically significant at the $\mathrm{p}<.05$ level or better (relationships from percent Hispanic to outcome, $p<.05$, one-tailed test). Chi-square, not significant; RMSEA $=0.000 ;$ TLI $=$ $1.010 ; \mathrm{IFI}=1.001 ; \mathrm{CFI}=1.000$.
In rural areas as displayed in Figure 2 basic institutional changes shown in the educational index and college degree measure demonstrate that classroom time spent engaged in environmental and other educational activities can pay off in environmental improvements as well as in many features commonly referred to as human and social capital (Putnam 1955, Flora and Flora 2011). Education programs in this case are ones carried out in classrooms, resulting in what some might characterize as "pester power" among schoolchildren. Rural farm children may serve as a very positive force in food retention and accumulation for distribution to those in disadvantaged positions of food insecurity. The positive effect of population is a redundancy (more people, more waste to be recycled), but the impact of a communities' type relative to population of veterans was, again, an unexpected finding (Kentor 2008, Kentor and Kick 2010).

We offer the overall interpretation that rural areas are unique contexts, relatively absent of a developed infrastructure to support recycling (especially curbside recycling), where attitudinal and behavioral factors increasingly influence recycling participation. By contrast, in more urban settings, infrastructural changes are the key to an improved recycling profile for the community. Our faith in these results is enhanced by the care we took in coding, the well-established estimation techniques we used, and by our introduction of statistical control variables to prevent false inferences in our estimation. Indeed, altogether we coded a wide assortment of variables as specified by the literature, but found they wash out in statistical significance when compared with the structural factors noted above.

Thus, we conclude from the more publicly visible and favorable forms of waste treatment represented in recycling that the approach to improving waste recovery rates should be different in rural and urban spaces. We even suggest a next level of tests that examine whether the distance from facilities in certain types of rural communities makes a difference in recycling rates. For example, in smaller areas with essentially no supporting infrastructure for recycling, we would expect the recycling rate to approach zero. In dense urban areas with convenient facilities, curbside service, the most effective program is demonstrated. Left open for future examination is: how can urban rates be further increased?

We are pleased to report several mechanisms are becoming increasingly available to a wider number of municipalities, and they have greatly increased the recycling recovery profiles of urban and rural areas alike. The number of Materials Recovery Facilities (MRF) has expanded significantly over the last decade increasing recovery numbers in North Carolina. Yet, earlier we also emphasized while recycling is a very useful approach to waste reduction concerns, these offsets should be viewed alongside the total pollution and toxin-inducing dynamics which coexist with recycling efforts. Enduring fiscal conditions in the state (and 
Citation: Kick EL, McKinney L and Thomson R (2016). Waste throughout North Carolina with Implications for Agricultural Production. J Agr Agri Aspect 2016: JAAA106.

elsewhere) point to the need for restructuring or even more efficacious and economically-incentivized mechanized means of waste recovery. The persistent efforts of NC DENR, as well as the larger federal EPA, are responsible for the overwhelming success in food and material recovery. However, these agencies are also responsible for treating the waste crisis across a wide variety of hazards, not only consumer waste. Ultimately, our goal is to examine all "offsets" to successful waste management, and food augmentation programs. But for now, given truncated space, we have chosen to examine a restricted set of pollution types that in contrast to favorable recycling results continue to pose serious threats to community and environmental health.

\section{Landfills}

In total, DENR reports an average of roughly 9.3 million tons of waste is generated annually and sent to 77 active landfills (DWM Municipal Solid Waste Annual Report). As reflected in the 2013 Solid Waste and Material Management, North Carolina has a total remaining capacity of roughly 380 million cubic yards (approximately 235 million tons). Landfills shown in Figure 3 exhibit a high degree of clustering, particularly when they are compared county-by-county. The distribution of one landfill site per county gives it a fairly scattered distribution throughout the state as a whole. This is also observed in the average nearest neighbor analysis output (p-value $=0.409227$ ) which suggests that in the state of $\mathrm{NC}$ as a whole the location of landfills is not statistically different from a random distribution. However, when county units are included in the spatial autocorrelation as well as high-low clustering analysis, landfills exhibit a pattern of clustering between counties.

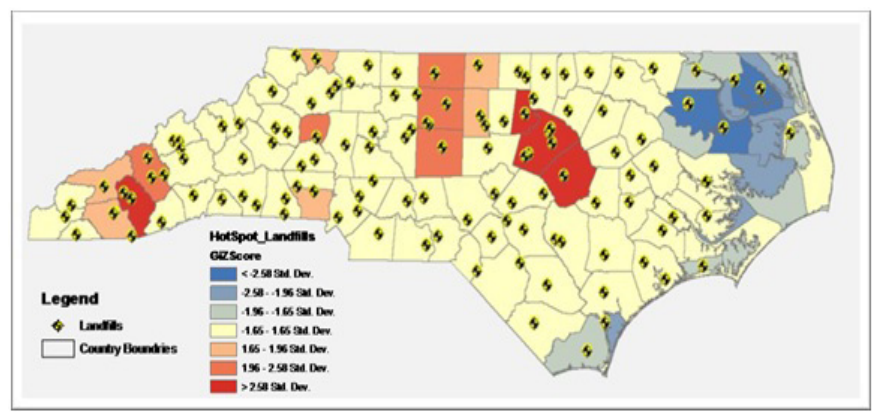

Figure 3: Hot-Spot Analysis Output of Landfill Sites (data collected by EPA Landfill Methane Outreach Program 2004).

Unfortunately, little can be said for the accuracy of the size or quantity of waste contained within the landfills. Future research might consider investigating the total tonnage of waste and the landfill proximity across a variety of demographic variables. The hot-spot extending from Wake County presents one type of concern. On the other hand access is a relative issue in the eastern part of the state. Historically Eastern Carolina has been home to poverty, food insecurity, and the production of tobacco, swine, poultry and eggs, soybeans, and sweet potatoes. It is the home of agricul- ture and poverty. While several of the commodities produced here contain the proteins that fight food insecurity, many are destined for "export" to other counties or even other countries for the wellbeing of foreign populations. It is a sad irony indeed that a population that is to some degree food insecure itself is home to hog-processing Smithfield foods, that reportedly produces $27,000,000$ pigs a year but after 2013 became the property of China in a $\$ 5$ to $\$ 7$ billion sale. Thus a major portion of the state's agricultural goods, particularly in Southeastern North Carolina now work to guarantee the food security of those at considerable distance. But another key question to be raised is: Where, precisely, does the rural Eastern Carolina resident, the rural resident, the farmer, dispose of all of his (her) waste when they are so deeply underserved by landfill possibilities? From the reports we were given, "the back 40" or "the river" were not uncommon. Once again convenience and inplace infrastructure come into play in the disposal of waste.

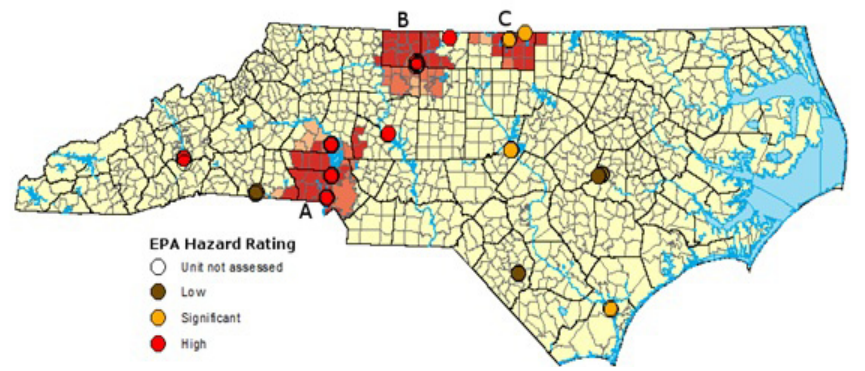

Figure 4: Hot-Spot Analysis Townships by Minimum Gallons of Coal Ash Dumps (datum collected by the Southern Alliance for Clean Energy 2013)

While there is essentially no theorization on Coal Ash Dumps, data analyses are instructive. Of the at least 50 reported coal ash dumps, 29 dumps have been rated high hazard by the EPA, meaning failure would likely result in the loss of human life. In figure 5 , the data analysis identifies thirteen primary concentrations of coal ash and of those, three regional areas (A, B, C) with greatly heightened concentrations. Coal ash has increased throughout the state since the 1990s and remains an elusive form of industrial pollution posing serious threats to $\mathrm{NC}$ communities. These threats have established a history throughout the state which includes incidents such as Flemington, located near Wilmington, $\mathrm{NC}$ in South Eastern North Carolina; in which the nearby Sutton 'coal ash basin' contaminated the groundwater (and the wells) of over 400 residents with a combination of toxins including arsenic (see USE PA 2000). The incident has resulted in a settlement of roughly $\$ 1.5$ million to subsidize the Cape Fear Public Utility Authority to begin establishing public waterlines to the community. While ratings may be high in the western part of the state, waterways below ground carry it eastward, again to those poor and often hungry residents nearer the ocean.

Nearly 80,000 North Carolinians live within 2 miles of the identified coal ash dumps. All sites are maintained by the Duke/ 


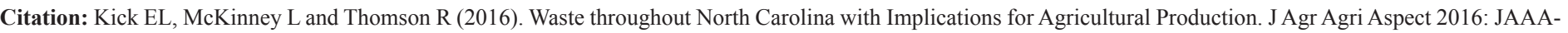
106.

Duke-Progress Corporation based out of Charlotte, NC. Given their status as a state monopoly, they are responsible for providing energy at the lowest cost possible and seek to externalize costs in the form of coal ash dumps. These growing dumps contain, among many things, mercury, chromium, selenium, lead, arsenic, boron, antimony, cadmium, molybdenum, thallium and leachate comprised of poisonous metals and other carcinogens. As identified by the EPA, these toxins are commonly tied to cancer of the bladder, lungs, skin, kidneys, nasal passages, liver and prostate (water.epa.gov 2014). Non-cancer effects include thickening and discoloration of the skin, stomach pain, nausea, vomiting, diarrhea, numbness in the hands and feet, partial paralysis and blindness (water.epa.gov 2014). The total size and exact tonnage of ash in these dumps remains unknown given the lack of data on the part of NC DENR in addition to multiple dumps not having been assessed. The hot-spots identified by our analysis of the data must be viewed in terms of total regional ash surrounding coal plant sites rather than potential contamination areas, and ultimate sites of environmental destruction much farther away. Thus we note the significant and widespread existence of coal ash dumps in Western and Midwestern North Carolina, as well as the site in Wilmington, North Carolina which is in the east, is "within reach" through waterways of the locus of the production and processing of swine, chicken, soybeans and sweet potatoes.

The average nearest neighbor analysis as well as high-low clustering between counties identified significant pockets of concentrated coal ash. The three primary regions of coal ash which are most alarming are the Catawaba River basin (A) in the South as well as the Upper Dan River (B) and Hyco/Lower Dan River (C) concentrations in the North. The Catawaba basin maintains the seven impoundments (six unassessed as to risk) at the Marshall Steam Plant on Lake Norman North, the four impoundments (two unassessed) at the recently retired Riverbend Steam Station and five impoundments (four unassessed) at the G.G. Allen Steam Plant to the south on Lake Wylie. All assessed dumps were identified as posing serious health risks to the surrounding community. Of the three plants, G.G. Allen Plant is the only Duke Energy station with five steam unit engines under one roof. This station was constructed in the 1950s and has a well-established legacy of pollution (e.g. the November 2012 four coal ash seepage points identified by the Catawaba River Keepers).

The Upper Dan River hot-spot is centered on the Belews Creek Steam Station which has four coal ash impoundments; two of the dumps have been confirmed as lacking liners while the others remained unassessed. The Dan River Steam Station outside Eden, NC has a similar four dump arrangement lacking liners and assessment. The Hyco/Lower Dan cluster has the Roxboro Steam Plant is one, This is where the Danville Spill occurred in 2014, tens of thousands of tons of coal ash and 27 million gallons of contaminated water spilled into the Dan River. of the largest power plants in the US with five dumps (at least 3 are missing liners), which is only 9.76 miles from the Mayo Steam Plant's two dumps (also missing at least two liners). One important note of interest to end our analysis of coal ash is, the under analyzed coal-ash connections made through the waterways of the state.

\section{Disaster-related lagoons and waterways}

The disaster-swine lagoon-waterway connection is under theorized, yet interesting data again emerge. The disaster-related consequences of Hurricane Matthew are still being evaluated by the state of North Carolina. In the wake of Hurricane Matthew, which dumped more than a foot of rain as far as 100 miles inland, 28 people lay dead, 2000 others were rescued, Interstate 95 was closed, chunks of interstate 40 were simply washed away, about $2,000,000$ poultry were drowned or euthanized as were 3,000 swine, 200 gallons of diesel fuel from a damaged tanker was trapped on flooded highway 55, and the entire state is well aware, once again, of being crippled by a serious climatic event. Animal and human waste, coal ash, fuel leaks, and more that may have polluted the Neuse, Pamlico, and Cape Fear rivers and tributaries still remain unassessed as the state simply attempts to gain its footing.

Our interest among these on-going human tragedies a month later is poultry and swine and the disposition of the manure they produce. In South Eastern North Carolina there are just five counties that turn out 10,000,000 hogs a year. These counties are close to the hot spot identified above, the coal-ash impacted waterways, and the relative absence of landfills and poverty extant for this part of the state. North Carolina's hog barns generate 10 billion gallons of fecal matter a year, which is stored in hog lagoons on the property of the larger agri-businesses of the state. Duplin County in South Eastern North Carolina has an estimated 2.3 million hogs. It is the leader among North Carolina's counties in producing chickens. Pig manure is filled with pathogenic bacteria, including anti-biotic resistant ones, and nitrates, among many other toxins, that feed dead-zones creating algae blooms. Untreated hog waste is also toxic due to high concentrations of nitrogen, phosphorus and airborne ammonia.

Some scientists have distinguished their careers documenting how the hog business as a system harms whole communities, sometimes when municipal intake systems are impacted, infecting the public water supply. When the affected communities are disproportionately comprised of the poor and African-Americans citizens, as they are with some frequency, the issue becomes one of environmental justice. Although the exact magnitude of damage still is far from being truly assessed, the concern described thus far is graphically elaborated in an article written for Mother Jones about sixteen years ago. In describing the consequences attending a prior hurricane in the area, the interviewee states:

"Hurricane Floyd washed 120,000,000 gallons of unsheltered hog waste into the Tar, Neuse, Roanoke, Pamlico, New and 


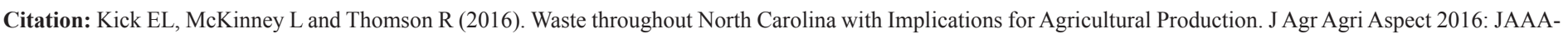
106.

Cape Fear rivers. Many of the pig lagoons of eastern North Carolina were several feet under water. Satellite photographs show a dark brown tide closing over the region's waterways, converging on the Albemarle-Pamlico Sound and feeding itself out to sea in a long, well-defined channel. Very little freshwater marine life remained behind. Tens of thousands of drowned pigs were strewn across the land. Beaches located miles from Smithfield lagoons were slathered in feces. A picture taken at the time shows a shark eating a dead pig three miles off the North Carolina coast."

We freely admit that counterbalancing serious challenges to the state's environmental circumstances, and associated issues of environmental justice, are the provision of jobs for many others who claim they would otherwise be unemployed, and the formation of a formidable regional system of interdependent agribusinesses. Duplin and proximal counties house the powerful enterprises that produce the feed for chicken and swine, agribusinesses recognizing the benefits of proximity to seed production in creating their lucrative animals-raising facilities, other agribusinesses that provide the slaughtering and packaging facilities for them, and still others which transport the products for distribution across the United States and export to a wide range of countries both nearby or distant. This complex covers the landscape of South Eastern North Carolina, and undoubtedly fuels local and state-wide economic development.

Yet, a study by researchers at the University of North Carolina and Johns Hopkins University also found elevated levels of hog-related fecal bacteria in waterways near hog operations. Other studies suggest that pathologies from memory retention to higher infant mortality rates appear to accompany proximity of communities to these waterways, suggesting the nature of the "trade-off" between economic growth as a plausible positive outcome and health, human and social capital deficits as plausible negative outcomes.

\section{Conclusions}

The state of North Carolina has made significant advancements in drawing down consumer waste to landfills through implementing a series of successful recycling and reuse programs throughout the state. These have been successful to some degree in processing a variety of materials including agricultural products that, unfortunately might otherwise have fed a number of food insecure indigenous consumers. Through SEM modeling of DENR and ACS data, we conclude that rural areas must maintain alternative waste management strategies than larger municipalities. Rural areas and unincorporated municipalities remain dependent to some degree upon access to county-operated drop-sites, although farmers in particular are both selectively impacted and "resourceful" in their disposition of unwanted waste. We mention again the irony of the massive production of food in an area where food produc- tion is coupled with some of the highest rates of food insecurity in the state. Residents here live among plenty but may not partake of it, whereas corporate distributors deliver a goodly share of the food that is produced to far distant places. Further investigation is needed to better understand the expansion of rural production and the distribution of both food and waste, and with respect to the latter, the construction of a more optimal waste infrastructure.

The spread of 95 gallon recycling bins has proven to be a huge success throughout larger municipalities in the state. It would be a very ambitious endeavor to obtain and analyze the geographies of the state and the recovery through recycling of the most useful materials otherwise destined for the landfill. In terms of food only, the widely cited figure is that $33 \%$ of food universally is simply wasted - more than enough to feed those who are food insecure now and their children who may be even more so by the year 2050 .

We acknowledge that the emphasis on individual recycling behavior and its favorable impacts for detoxifying North Carolina largely downplays the neglect of the totality of uncaptured toxins that have accumulated throughout the state. The contradictory dynamics noted in our study on the one hand show a series of complex policy responses to divert waste and prevent the further expansion of landfills while simultaneously decreasing the number of incinerators throughout the state. At the same time, these locations largely remain subject to industrial demand. Swine lagoons, superfund sites, national pollution discharge elimination sites, nuclear plants, industrial sites, fracking pads, illegal landfills, incinerators and power plants must be included to understand the holistic effects of the waste crisis throughout this state, or any state. The coal ash dumps represent for many private actors circumventing large-scale policy efforts. For instance, it is widely argued that uninvestigated dumps presently remain despite the recent wave of public scrutiny following the February 2, 2014 contamination of the Dan River in which 39,000 tons of coal ash which coated over 65 miles of river bend downstream. We will not speculate as to how such a toxic form of waste was permitted to accumulate in such quantities lacking minimal infrastructure. However, it is apparent that a wider scope of analysis that goes beyond consumer behavior is necessary to better understand the vast expansion of waste. The neglected areas, where clustering of toxins and the absence of convenient waste disposal present the largest threats to overshooting our state's environmental capacity for regeneration. These dynamics and the threats posed by the clustering of toxins pose similar threats throughout all fifty states, as well as the globe. The proximity of such hazards to agriculture and specifically commercial food- producing and neighboring areas remains an essentially unstudied dynamic, as does the absence of convenient landfill facilities to the agricultural community.

Our three studies point to the particular vulnerabilities of ru- 
Citation: Kick EL, McKinney L and Thomson R (2016). Waste throughout North Carolina with Implications for Agricultural Production. J Agr Agri Aspect 2016: JAAA106.

ral North Carolina, especially Southeastern North Carolina. Areas of concerns over toxins may be found throughout the state. However, results derived from multiple methodologies show that the overall well-being of the state comes at particular costs to areas and populations that can be pinpointed by the elementary drawing of maps showing the areas where the highest hazards exist, to far more sophisticated techniques which validate the lower-lever conclusions reached with rudimentary analyses. Agricultural areas by their nature located in rural locales bear the brunt of environmental impact for the state, while providing an undeniable benefit to the

\section{Appendix A}

Table 1: AVERAGE NEAREST NEIGHBOR ANALYSIS (between all sites in the state)

\begin{tabular}{|c|c|c|c|c|c|c|c|}
\hline $\begin{array}{c}\text { Unit of Pollu- } \\
\text { tion }\end{array}$ & $\begin{array}{c}\text { Observed } \\
\text { Mean }\end{array}$ & $\begin{array}{c}\text { Expected } \\
\text { Mean }\end{array}$ & $\begin{array}{c}\text { Nearest Neighbor } \\
\text { Ratio }\end{array}$ & Z-Score & P-Value & $\begin{array}{c}\text { Cluster / Ran- } \\
\text { dom / }\end{array}$ \\
\hline Dispersed & & & & & & & $\begin{array}{c}\text { The pattern does not ap- } \\
\text { pear to be significantly } \\
\text { different than random }\end{array}$ \\
\hline Landfills & 18821.908 & 19574.145 & 0.096157 & -0.825255 & .409227 Random \\
\hline Coal Ash Dumps & 553.4798 & 19084.452 & 0.029002 & -14.86 & $<0.0001$ & $\begin{array}{c}\text { There is a less than } \\
\text { clustered pattern would } \\
\text { appear at random }\end{array}$ \\
\hline
\end{tabular}

Table 2: SPATIAL AUTOCORRELATION (Global Moran 1) (between Counties)

\begin{tabular}{|c|c|c|c|c|c|c|c|}
\hline $\begin{array}{c}\text { Unit of Pollu- } \\
\text { tion }\end{array}$ & Moran's Index & $\begin{array}{c}\text { Expected } \\
\text { Index }\end{array}$ & $\begin{array}{c}\text { Variance of } \\
\text { County Pollution }\end{array}$ & Z-Score & P-Value & $\begin{array}{c}\text { Cluster / Random } \\
\text { / Dispersed }\end{array}$ \\
\hline Landfills & 0.269946 & -0.007874 & 0.004825 & 3.99546 & 0.000063 & $\begin{array}{c}\text { There is a less than } 1 \% \\
\text { likelihood that this clus- } \\
\text { ter pattern would appear } \\
\text { by random }\end{array}$ \\
\hline Coal Ash Dumps & -.1136 & -.0159 & .01334 & -.84687 & .397064 & $\begin{array}{c}\text { The pattern does not ap- } \\
\text { pear to be significantly } \\
\text { different than random }\end{array}$ & Random \\
\hline
\end{tabular}

Table 3: SPATIAL AUTOCORRELATION (Global Moran 1) (between Counties)

\begin{tabular}{|c|c|c|c|c|c|c|c|}
\hline $\begin{array}{l}\text { Unit of Pollu- } \\
\text { tion }\end{array}$ & $\begin{array}{c}\text { Observed Gen. } \\
\text { G }\end{array}$ & $\begin{array}{c}\text { Expected } \\
\text { Gen G }\end{array}$ & $\begin{array}{c}\text { Variance of } \\
\text { County Pollution }\end{array}$ & Z-Score & P-Value & Conclusion & $\begin{array}{c}\text { High / Random / } \\
\text { Low }\end{array}$ \\
\hline Landfills & 0.009342 & 0.007874 & 0.0001 & 33.333991 & 0.000856 & $\begin{array}{l}\text { There is a less than } \\
1 \% \text { likelihood that this } \\
\text { cluster would appear by } \\
\text { random }\end{array}$ & High-Cluster \\
\hline $\begin{array}{l}\text { Coal Ash } \\
\text { Dumps* }\end{array}$ & 0.000112 & 0.000095 & 0.0000 & 2.275312 & 0.022887 & $\begin{array}{l}\text { There is a less than } \\
1 \% \text { likelihood that this } \\
\text { cluster would appear by } \\
\text { random }\end{array}$ & High-Cluster \\
\hline
\end{tabular}


Citation: Kick EL, McKinney L and Thomson R (2016). Waste throughout North Carolina with Implications for Agricultural Production. J Agr Agri Aspect 2016: JAAA106.

\section{Appendix B}

The General $G$ statistic of overall spatial association is given as:
\[ G=\frac{\sum_{i=1}^{n} \sum_{j=1}^{n} w_{i, j} x_{i} x_{j}}{\sum_{i=1}^{n} \sum_{j=1}^{n} x_{i} x_{j}}, \forall j \neq i \]

where $x_{i}$ and $x_{j}$ are attribute values for features $i$ and $j$, and $w_{i, j}$ is the spatial weight between feature $i$ and $j$.

The $z_{G}$-score for the statistic is computed as:

$$
z_{G}=\frac{G-\mathrm{E}[G]}{\sqrt{\mathrm{V}[G]}}
$$

where:

$$
\begin{aligned}
\mathrm{E}[G] & =\frac{\sum_{i=1}^{n} \sum_{j=1}^{n} w_{i, j}}{n(n-1)}, \forall j \neq i \\
\mathrm{~V}[G] & =\mathrm{E}\left[G^{2}\right]-\mathrm{E}[G]^{2}
\end{aligned}
$$

The Getis-Ord local statistic is given as:

$$
G_{i}^{*}=\frac{\sum_{j=1}^{n} w_{i, j} x_{j}-\bar{X} \sum_{j=1}^{n} w_{i, j}}{S \sqrt{\frac{\left[n \sum_{j=1}^{n} w_{i, j}^{2}-\left(\sum_{j=1}^{n} w_{i, j}\right)^{2}\right]}{n-1}}}
$$

where $x_{j}$ is the attribute value for feature $j, w_{i, j}$ is the spatial weight between feature $i$ and $j, n$ is equal to the total number of features and:

$$
\begin{aligned}
\bar{X} & =\frac{\sum_{j=1}^{n} x_{j}}{n} \\
S & =\sqrt{\frac{\sum_{j=1}^{n} x_{j}^{2}}{n}-(\bar{X})^{2}}
\end{aligned}
$$

\begin{tabular}{|c|c|c|c|}
\hline $\begin{array}{l}\text { ReUse Pro- } \\
\text { gram Index }\end{array}$ & 2009 & $\begin{array}{l}\text { SWMAR; \#14 } \\
\text { and \#15 }\end{array}$ & $\begin{array}{c}\text { Summation of values to questions: } \\
\text { Did your local government offer a } \\
\text { waste exchange or reuse program? } \\
\text { If yes, please indicate which pro- } \\
\text { grams were available: Swap shop/ } \\
\text { shed (number of sheds in use); } \\
\text { Waste exchange; pallet exchange; } \\
\text { paint exchange (number of gallons } \\
\text { recovered) }\end{array}$ \\
\hline $\begin{array}{c}\text { Total } \\
\text { Recycling } \\
\text { Tonnage }\end{array}$ & 2009 & $\begin{array}{c}\text { SWMAR; } \\
\text { Recycling Ton- } \\
\text { nages Total tons }\end{array}$ & $\begin{array}{c}\text { Total tonnage of recyclables recov- } \\
\text { ered from all program }\end{array}$ \\
\hline \multicolumn{4}{|l|}{ Figure 2} \\
\hline Variable & Year & Source & Definition \\
\hline$\%$ Veterans & 2009 & $\begin{array}{l}\text { American Com- } \\
\text { munity Survey }\end{array}$ & $\begin{array}{l}\text { Percentage of veterans in the } \\
\text { Population }\end{array}$ \\
\hline$\%$ Hispanic & 2009 & $\begin{array}{l}\text { American } \\
\text { Community } \\
\text { Survey }\end{array}$ & $\begin{array}{l}\text { Percentage of Hispanics in the } \\
\text { population }\end{array}$ \\
\hline $\begin{array}{l}\% \text { College } \\
\text { Degree }\end{array}$ & 2009 & $\begin{array}{l}\text { American Com- } \\
\text { munity Survey }\end{array}$ & $\begin{array}{l}\text { Percentage of college degree hold- } \\
\text { ers in the population }\end{array}$ \\
\hline Population & 2009 & $\begin{array}{l}\text { American Com- } \\
\text { munity Survey }\end{array}$ & Number of persons \\
\hline $\begin{array}{l}\text { Income per } \\
\text { capita }\end{array}$ & 2009 & $\begin{array}{l}\text { American Com- } \\
\text { munity Survey }\end{array}$ & Average income per person \\
\hline $\begin{array}{l}\text { Education } \\
\text { Index }\end{array}$ & 2009 & $\begin{array}{l}\text { SWMAR; \#60 } \\
\text { and \#61 }\end{array}$ & $\begin{array}{l}\text { Summation of values to questions: } \\
\text { Did you local government have } \\
\text { an education program to inform } \\
\text { the citizens specifically about } \\
\text { solid waste management issues/ } \\
\text { activities? Which of the following } \\
\text { solid waste education activities } \\
\text { did you local government conduct } \\
\text { of produce (check all that apply): } \\
\text { radio/TV advertisements; Block } \\
\text { leader program; newspaper ads/ } \\
\text { articles; mass mailings/utility bills, } \\
\text { etc.; award program for busi- } \\
\text { nesses; take-home items; telephone } \\
\text { hotline; website; RE3 campaign; } \\
\text { The recycle guys; reward/incen- } \\
\text { tive program; workshops, forums } \\
\text { or conferences; public schools } \\
\text { programs; special events; other }\end{array}$ \\
\hline
\end{tabular}

The $G_{i}^{*}$ statistic is a $z$-score so no further calculations are required.

\begin{tabular}{|c|c|c|c|}
\hline \multicolumn{2}{|c|}{ Figure 1 } \\
\hline Variable & Year & Source & Definition \\
\hline $\begin{array}{c}\text { Avg. Fam } \\
\text { Income }\end{array}$ & 2009 & $\begin{array}{c}\text { American Com- } \\
\text { munity Survey }\end{array}$ & $\begin{array}{c}\text { Average Family Income for the } \\
\text { Municipality }\end{array}$ \\
\hline $\begin{array}{c}\text { Households } \\
\text { participating } \\
\text { in CRB }\end{array}$ & 2009 & $\begin{array}{c}\text { Solid Waste } \\
\text { Management } \\
\text { Annual Report } \\
\text { (SWMAR; see } \\
\text { Appendix B); } \\
\# 19 c\end{array}$ & $\begin{array}{c}\text { Estimate the number of households } \\
\text { that regularly participate in the } \\
\text { curbside recycling program }\end{array}$ \\
\hline ABC Index & 2009 & SWMAR; \#33 & $\begin{array}{c}\text { Summation of values to ques- } \\
\text { tions: Does your local government } \\
\text { provide on-site recycling services } \\
\text { services provided? Drop-off sites } \\
\text { provided? Estimated number of } \\
\text { ABC accounts? }\end{array}$ \\
\hline
\end{tabular}

APPENDIX C. Municipalities included (*--indicates municipalities included in the rural sub-sample, Figure 2).

APEX

ARCHDALE

ASHEVILLE

AUTRYVILLE*

AYDEN

BAKERSVILLE*

BANNER ELK*

BEECH MOUNTAIN*

BETHANIA*

BEULAVILLE*

BILTMORE FOREST*
BLACK CREEK*

BOONE

BOONVILLE*

BREVARD

BRUNSWICK*

BURLINGTON

BURNSVILLE*

BUTNER

CAJAH MOUNTAIN

CALABASH*
CAPE CARTERET*

CARY

CATAWBA*

CHADBOURN*

CLEMMONS

CLINTON

CLYDE*

CONNELLY SPRINGS*

CONOVER

COOLEEMEE* 
Citation: Kick EL, McKinney L and Thomson R (2016). Waste throughout North Carolina with Implications for Agricultural Production. J Agr Agri Aspect 2016: JAAA106.

\begin{tabular}{|c|c|c|}
\hline CORNELIUS & LELAND* & SANTEETLAH* \\
\hline CREEDMOOR* & LEXINGTON & SEDALIA* \\
\hline DALLAS & LIBERTY & SHALLOTTE* \\
\hline DENTON* & LINDEN* & SHARPSBURG* \\
\hline DUNN & MADISON* & SIMPSON* \\
\hline EAST ARCADIA* & MARSHVILLE* & SMITHFIELD \\
\hline EAST LAURINBURG* & MAYSVILLE* & SNOW HILL* \\
\hline EASTOVER & MIDLAND* & SOUTHPORT* \\
\hline EDENTON & MINERAL SPRINGS* & ST. JAMES* \\
\hline ELIZABETH CITY & MINT HILL & STALLINGS \\
\hline ELKIN & MOCKSVILLE & STANLEY \\
\hline ELLENBORO* & MONROE & STEDMAN* \\
\hline FAIR BLUFF* & MONTREAT* & STEM* \\
\hline FARMVILLE & MOORESVILLE & SURF CITY* \\
\hline FLETCHER & MOREHEAD CITY & SWANSBORO* \\
\hline FOUNTAIN* & MORGANTON & SYLVA* \\
\hline GAMEWELL & MORRISVILLE & TAR HEEL* \\
\hline GARLAND* & MORVEN* & TARBORO \\
\hline GARNER & MURPHY* & TRINITY \\
\hline GASTONIA & NEW BERN & VALDESE \\
\hline GATESVILLE* & NEWPORT & WADE* \\
\hline GRAHAM & NORTH WILKESBORO & WAGRAM* ${ }^{*}$ \\
\hline GREEN LEVEL* & OAK ISLAND & WAKE FOREST \\
\hline GREENSBORO & ORIENTAL* & WASHINGTON \\
\hline GREENVILLE & PARKTON* & WEDDINGTON \\
\hline GRIFTON* & PINETOPS* & WENDELL \\
\hline GRIMESLAND* & PITTSBORO* & WESLEY CHAPEL \\
\hline HARRELLS* & PLEASANT GARDEN & WEST JEFFERSON* \\
\hline HARRISBURG & RALEIGH & WHITEVILLE \\
\hline HEMBY RIDGE* & REIDSVILLE & WILSONS MILLS* \\
\hline HENDERSON & RICHLANDS* & WINFALL* \\
\hline HERTFORD* & ROBBINSVILLE* & WINGATE* \\
\hline HIGH POINT & ROBERSONVILLE* & WRIGHTSVILLE \\
\hline HIGHLANDS* & ROWLAND* & BEACH \\
\hline HUDSON & SALEMBURG* & YADKINVILLE \\
\hline JEFFERSON* & SANDY CREEK* & YOUNGSVILLE* \\
\hline KURE BEACH* & SANFORD & ZEBULON \\
\hline
\end{tabular}

\section{References}

1. Ando K, Ohnuma S, Blobaum A, Matthies E, Sugiura J (2010)Determinants of Individual and Collective Pro-Environmental Behaviours - Comparing Germany and Japan. Journal of Environmental Information Science. 38: 21-32.

2. Kenneth B (1989)Structural Equations with Latent Variables. New York, NY: John Wiley.

3. Barbara BN (2009) Structural Equation Modeling with AMOS. New York, NY: Routledge.

4. Richard B (1990) Dumping in Dixie: Race, Class, and Environmental Quality. Boulder, CO: Westview Press.

5. Richard B (2005)The Quest for Environmental Justice: Human Rights and the Politics of Pollution. San Francisco, CA: Sierra Club Books.

6. Stephen B (1996) "Raw Material and the Global Economy: Oversights and Distortions in Industrial Ecology." Society and Natural Resources. 9: 419-429.

7. Stephen B and Ciccantell P (2005) Globalization and the Race for Resources. Baltimore, MD: Johns Hopkins University Press.

8. Rees WE1 and Wackernagel M (2013) The shoe fits, but the footprint is larger than earth. PLoSBiol 11: e1001701.

9. Goodman, Julie, Hudson T and Monteiro R (2010) "Cancer Cluster Investigation in Residents Near a Municipal Landfill. Human and Ecological Risk Assessment. 16: 1339-1359.

10. United States Accounting Office. (2006) "Additional efforts could increase municipal recycling." Washington, DC: GAO.

11. Guagnano GA, Stern PC and Dietz T (1995) "Influences on attitudebehavior relationships - A natural experiment with curbside recycling." Environment and Behavior 27: 699-718.

12. Guerin D, Crete J and Mercier (2001) "A multilevel analysis of the determinants of recycling behavior in the European countries." Social Science Research 30: 195-218.

13. Hornik J, Cherian J, Madansky M, and Narayana C (1995) "Determinants of Recycling Behavior: A Synthesis of Research Results." The Journal of Socio-Economics 24: 105-127.

14. Ludemann C (1999) "Recycling behavior, thresholds and their explanation. an empirical test of hypotheses concerning environmental actions." KolnerZeitschrift Fur Soziologie Und Sozialpsychologie 51:532-+

15. Mainieri T, Barnett EG, Valdero TR, Unipan JB, Oskamp S (1997)"Green buying: The influence of environmental concern on consumer behavior." Pp. 189-204.

16. Martinez MD and Scicchitano MJ (1998) "Who listens to trash talk? Education and public media effects on recycling behavior." Social Science Quarterly 79: 287-300.

17. Meadows, Donella, RandersJ and Meadows D (2004). Limits to Growth. White River Junction, VT: Chealsea Green Publishing Company.

18. Nonami H, Sugiura J, Ohnuma S, Yamakawa H, Hirose Y (1997)"The roles of various media in the decision making processes for recycling behavior: A path analysis model." Japanese Journal of Psychology 68: 264-271.

19. North Carolina Department of Environment and Natural Resources. (2011) "Coal Ash Annual Report."

20. Pellow and David N (2002) Garbage Wars: The Struggle for Environmental Justice in Chicago. Cambridge, MA: The MIT Press.

21. Saphores JDM, Nixon H, Ogunseitan OA, Shapiro AA(2006)"Household willingness to recycle electronic waste - An application to California." Environment and Behavior 38: 183-208.

22. Terry DJ, Hogg MA, White KM (1999) "The theory of planned behavior: Self-identity, social identity and group norms." British Journal of Social Psychology 38: 225-244.

23. Weinberg, Adam, PellowDN, SchnaibergA(2000)Urban Recycling and the Search For Sustainable Community Development. Princeton, NJ: Princeton University Press.

24. United Nations Intergovernmental Panel on Climate Change -Working Group 1. (2013). "Climate Change: The Physical Science Basis."

25. United States Environmental Protection Agency. 2000. "Technologies and Costs of Removal of Arsenic from Drinking Water." Washington, D.C.. Retrieved March 12, 2014 from http://water.epa.gov/lawsregs/ rulesregs/sdwa/arsenic/index.cfm.

26. United Nations Brudtland Commission. 1987. "World Commission on Environment and Development Report." 